\title{
Skipping the Blockade Run: Andile Dyalvane and Camagu
}

\section{By: Elizabeth Perrill}

Elizabeth Perrill, "Skipping the Blockade Run: Andile Dyalvane and Camagu," Critical Interventions: Journal of African Art History and Visual Culture, vol. 12,1, 2018. pp. 97-106. https://doi.org/10.1080/19301944.2018.1424439

This is an Accepted Manuscript of an article published by Taylor \& Francis in Critical Interventions: Journal of African Art History and Visual Culture on 30 March 2018, available online: http://www.tandfonline.com/10.1080/19301944.2018.1424439.

***(C) 2018 Critical Interventions: Journal of African Art History and Visual Culture. Reprinted with permission. No further reproduction is authorized without written permission from Taylor \& Francis. This version of the document is not the version of record. Figures and/or pictures may be missing from this format of the document. ***

\begin{abstract}
:
Within the context of this special issue on African art markets, this artist's profile brings to the fore transforming and increasingly fractured contexts of artistic production and consumption. In particular, Andile Dyalvane's career highlights the fact that many contemporary artists working on the African continent are working from positions outside of international or domestic markets in carving, metalworking, or masquerade, media that have dominated Euro-American conceptualizations of African arts in the past 100 years. The work of Dyalvane, a ceramic artist based in Cape Town, South Africa, is historicized as emerging from South African institutions of higher education and infrastructures of ceramic and design promotions. Dyalvane's ability to tap into new international art trends that increasingly foregrounding ceramic arts, as well as his assertion of a philosophy of giving thanks summarized by the term Camagu, are highlighted in this early to mid-career artist's profile.
\end{abstract}

Keywords: South Africa $\mid$ African art | ceramics $\mid$ Andile Dyalvane | Cape Town

\section{Article:}

Andile Dyalvane, a ceramic artist based in Cape Town, South Africa, is harnessing support structures for visual art production that circumvent preconceptions conjured by the phrase, "the African art market" (Figures 1 and 2). Dyalvane and his peers are dubbed designers, artists, and makers or are named by media-specific labels — ceramists, metalsmiths, furniture designers, fashion designers, woodworkers. Whatever the verbiage, there is a groundswell of entrepreneurially minded arts activity in Cape Town. These young creative professionals are only tangentially impacted by the specific "ego-systems" of authority and taste discussed in this special issue, concepts of "the African art market" grounded in the consumption of carved wooden or cast metal works as export commodities or objects of connoisseurship. Of course, carvers and metalsmiths selling to export markets always had multiple markets and audiences,

\footnotetext{
${ }^{1}$ This neologism is a reference to the term used by Forni and Steiner in the opening of this special issue.
} 
both international and domestic. Nevertheless, there is an important difference at play in Dyalvane's milieu. Theoretical shifts sparked by the new craft movement and expanded vocabularies of what constitutes museum-worthy media worldwide have been catalysts in the dissolution of barriers that have separated labels such as "fine art," "fashion," or "design." These conceptual changes have, in turn, made for a far less unified market ecosystem, one that is only starting to turn its attentions to the expansive infrastructures of design and media-specific making that have been thriving throughout the African continent.

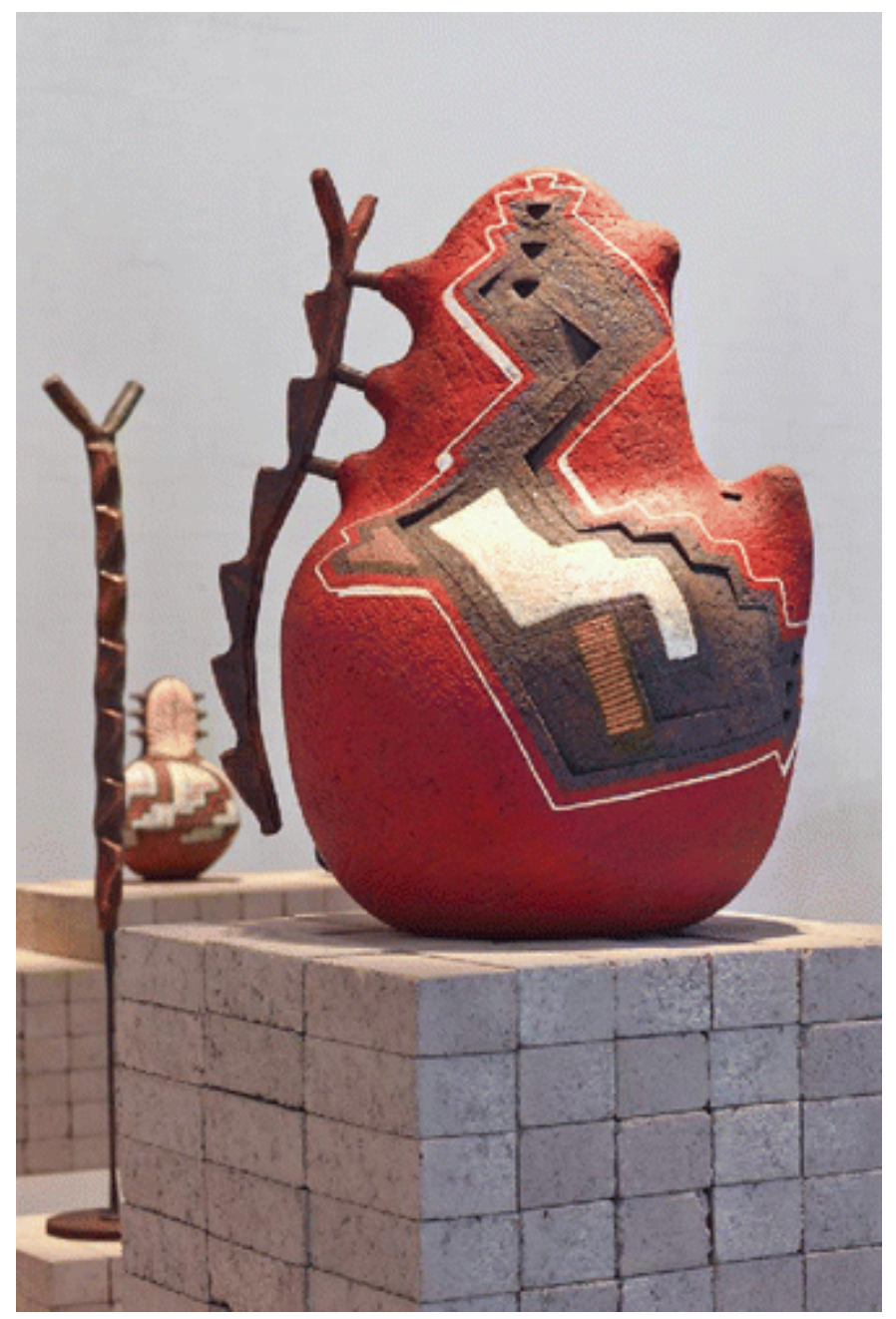

Figure 1. Andile Dyalvane, Idladla Exhibition Installation shot. Photo credit: Micky Hoyle, 2017.

The "Making Africa: A Continent of African Design" exhibition, a pivotal moment in Dyalvane's vita, bears witness to new market shifts. Curated by Amelie Klein with Consulting Curator Okwui Enwezor, "Making Africa" launched at the Vitra Design Museum, Weil am Rein, Germany in 2015, traveled to the Museo Guggenheim Bilbao during 2015-2016, and was featured at the High Museum in Atlanta 2017-2018 (Figure 3). This exhibition is a testament to expanding global interests in visual expression that eschew siloed canons of "traditional African," "fine art," "design," or "architecture." Photographers, sculptors, and multimedia artists familiar to African art historians, such as Seydou Keïta, Zanele Muholi, Gançalo Mabunda, and 
Robin Rhode, are certainly featured in this exhibition, but "Making Africa" also makes space for furniture designers, architects, and ceramists.

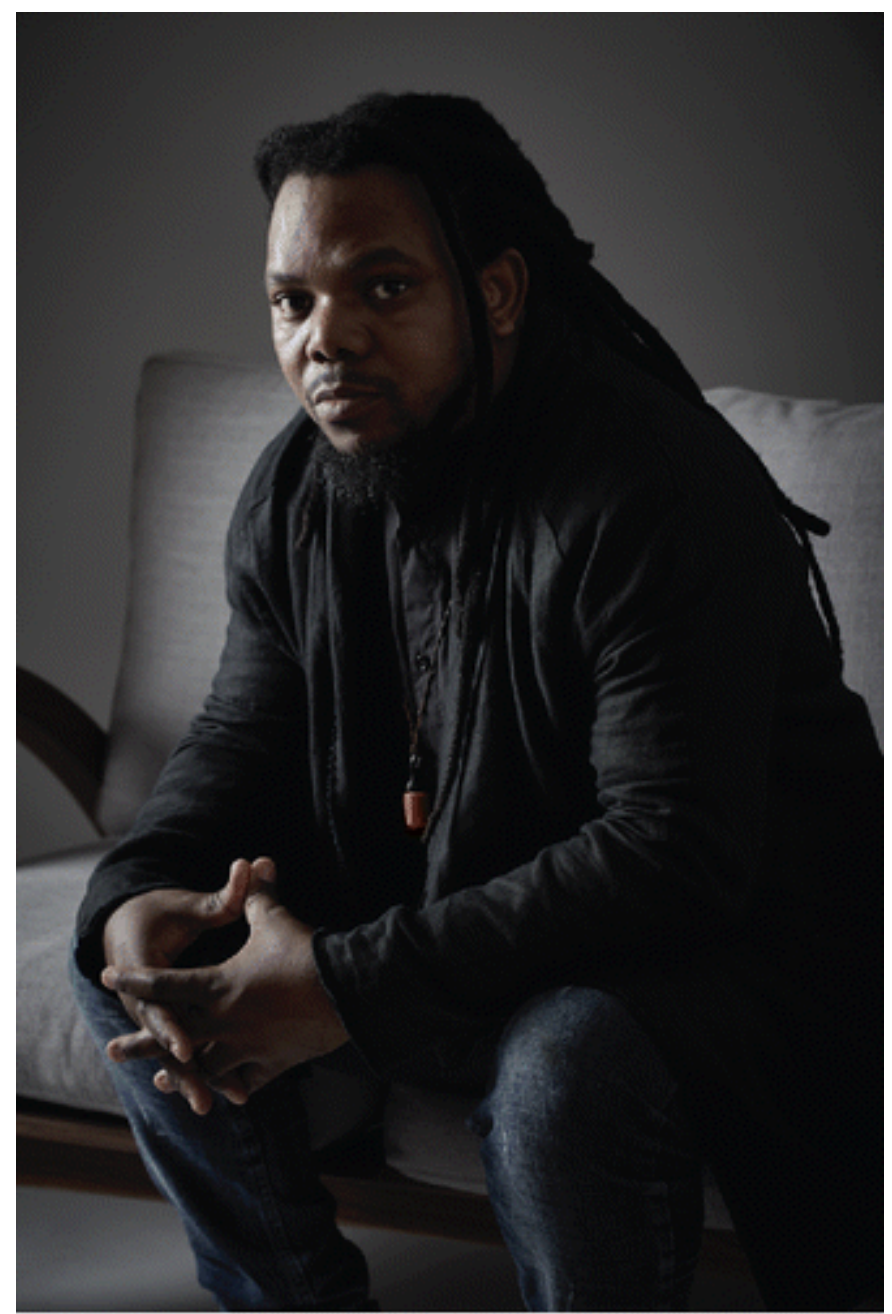

Figure 2. Andile Dyalvane, 2017. Photo credit: Southern Guild, 2017.

For Dyalvane's career, it is pivotal that the "Making Africa" exhibition not only features ceramic works, but also acknowledges that ceramists working outside of indigenous, low-fired ceramic wares are an active part of African artistic art worlds. Ceramic innovation and works created in high-fired stoneware have been an active part of expanding media-specific innovations since at least the mid-20th century. We need only look to the many artists creating facades, nationalist iconography of the modernist era, and domestic wares for evidence of this technological adaptation (Onuzulike). El Anatsui's Chambers of Memory or Gbeze forms from the 1970s are now canonical objects in the history of African arts (Rogers). However, the integration of ceramics into globally toured exhibitions is still rare. Few knew scholars of Anatsui's ceramic wares prior to the El Anatsui: When I Last Wrote to You About Africa touring exhibition, and ceramic wares still lay at the periphery of Anatsui's work, an early experiment tied to the roots of Nigerian stoneware traditions in the university system (Smith). Similarly, high-fired stoneware ceramics from many African centers are at the fringes. In this way, "Making Africa" was an 
expectation-shattering exhibition; ceramics were integrated into the fabric of design and arts with a high degree of fluidity and equality.

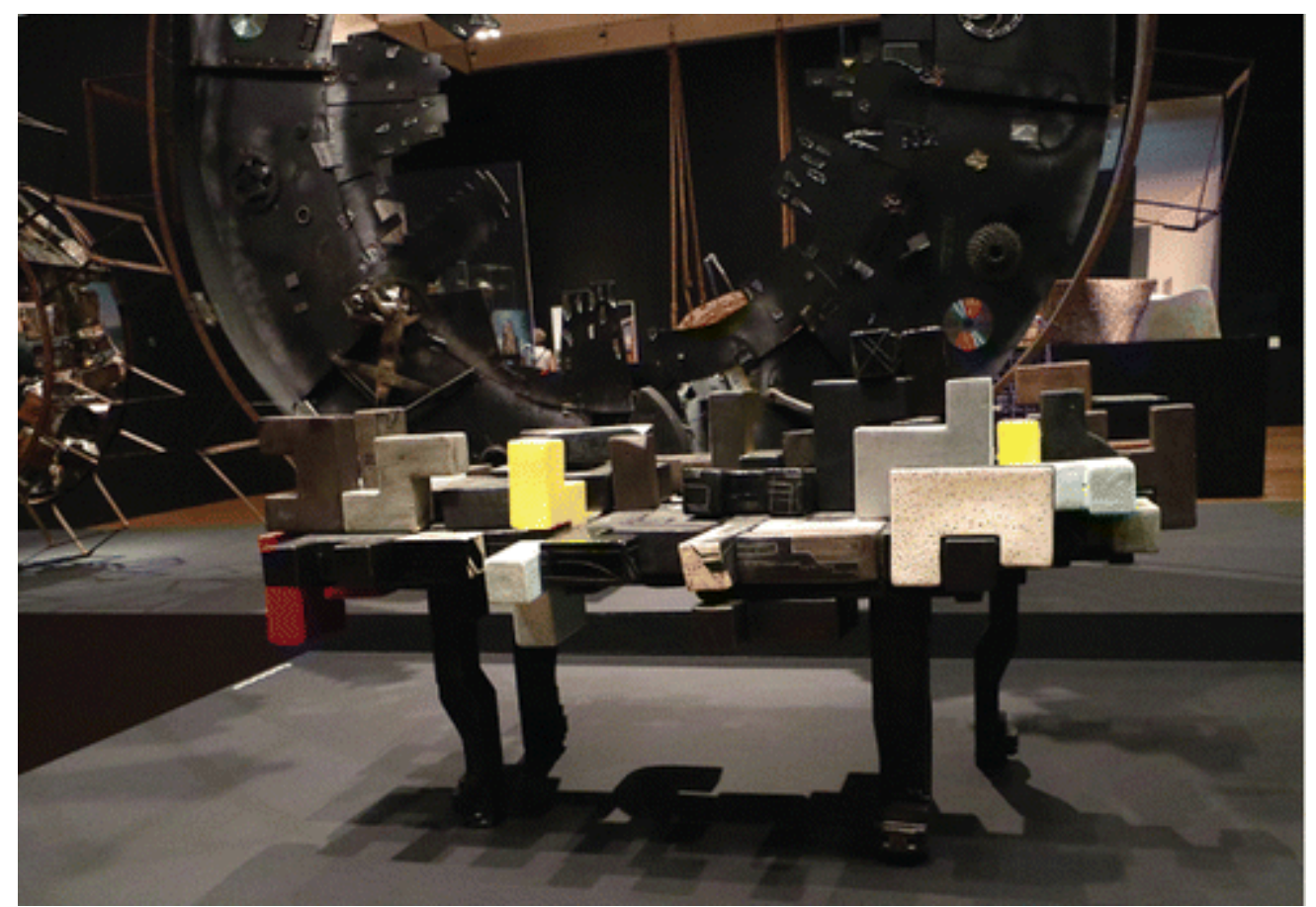

Figure 3. Docks Table, 2013, edition of 5, ceramics, glass, and steel. Imiso Ceramics, Andile Dyalvane and Zizipho Poswa. Installation Image, Making Africa: A Continent of Contemporary Design, High Museum of Art, Oct. 14, 2017-Jan. 7, 2018. Photo credit: Chris Higa.

Of course, "Making Africa: A Continent of African Design," in its title and its execution, also reinscribes the mental construction of Africa as a continent that somehow naturally stands as a unit. This overarching continental category can be a useful conceptual, political, or marketing tool, so its reassertion is certainly understandable. Indeed, at times, it is necessary to use the overarching African label for museum-going audiences in Europe and the United States that are still catching up to the sophistication and breadth of African artistic cultures. This is certainly a reminder that, despite shifting art world or art market definitions of what media or mental categorizations of objects or practices are welcome into museum spaces, the overarching geographic and post-colonial categories persist.

When I was approached for this artist's portfolio, special issue co-editor Silvia Forni asked if I might know of an artist who reflects/crosses boundaries between craft and high-art challenging different market discourses. Forni's bifurcated question referring to craft and high-art markets posed a conceptual problem when I thought of Dyalvane and other South African artists who might fit this description. The experiences of markets and geographies lie at the heart of this dilemma. Artists from West Africa-Hervé Youmbi, Emo de Medeiros, or Abdoulaye Konaté, to name a few - certainly made sense in the context of this special issue. They are blockade runners, breaking into various market niches, crossing boundaries, and finding safe harbor in lucrative "fine art" markets. These artists engage with the media of masquerade or textiles. They intersect with art histories of West Africa that are decidedly influenced by connoisseurship rooted in art markets explored at length in this special issue. The murmurs of authenticities and 
consumption patterns established by a gauntlet of tastemakers crossing between Europe, the United States, and western or central Africa over the past century give one an impression of Youmbi, de Medeiros, and Konaté and their peers braving embattled lines of informal and formal institutional gatekeepers and creating new market routes.

Andile Dyalvane enters into this discourse from a very different position, both geographically and conceptually. He and his peers have, in some ways, skipped the blockade run. They are not required to confront and break through the same histories of connoisseurship and preconceptions surrounding traditional West or Central African work. Yet in Cape Town, one of the world's most wealthy art harbors, battle lines of gentrification in the market for modern and contemporary African art, as discussed in Chika Okeke-Agulu's New York Times opinion piece (2017), are being drawn. Dyalvane exists inside the harbor of the South Africa economic boom, figuratively and literally. The artistic gentrification to which Okeke-Agulu referred is draining African nations of cultural patrimony, and Cape Town holds a complex position in this shifting geography. In this artistically minded harbor, all eyes are turned toward the opening of the Zeitz MOCCA. South African artists now have the chance to engage with rich histories of modern and contemporary art from across the continent. However, the South Africa art world and art worlds spread throughout the continent are well aware of South Africa's established record of xenophobia. The consolidation of artistic wealth in a handful of urban centers across the continent may be only a small step in confronting artistic gentrification.

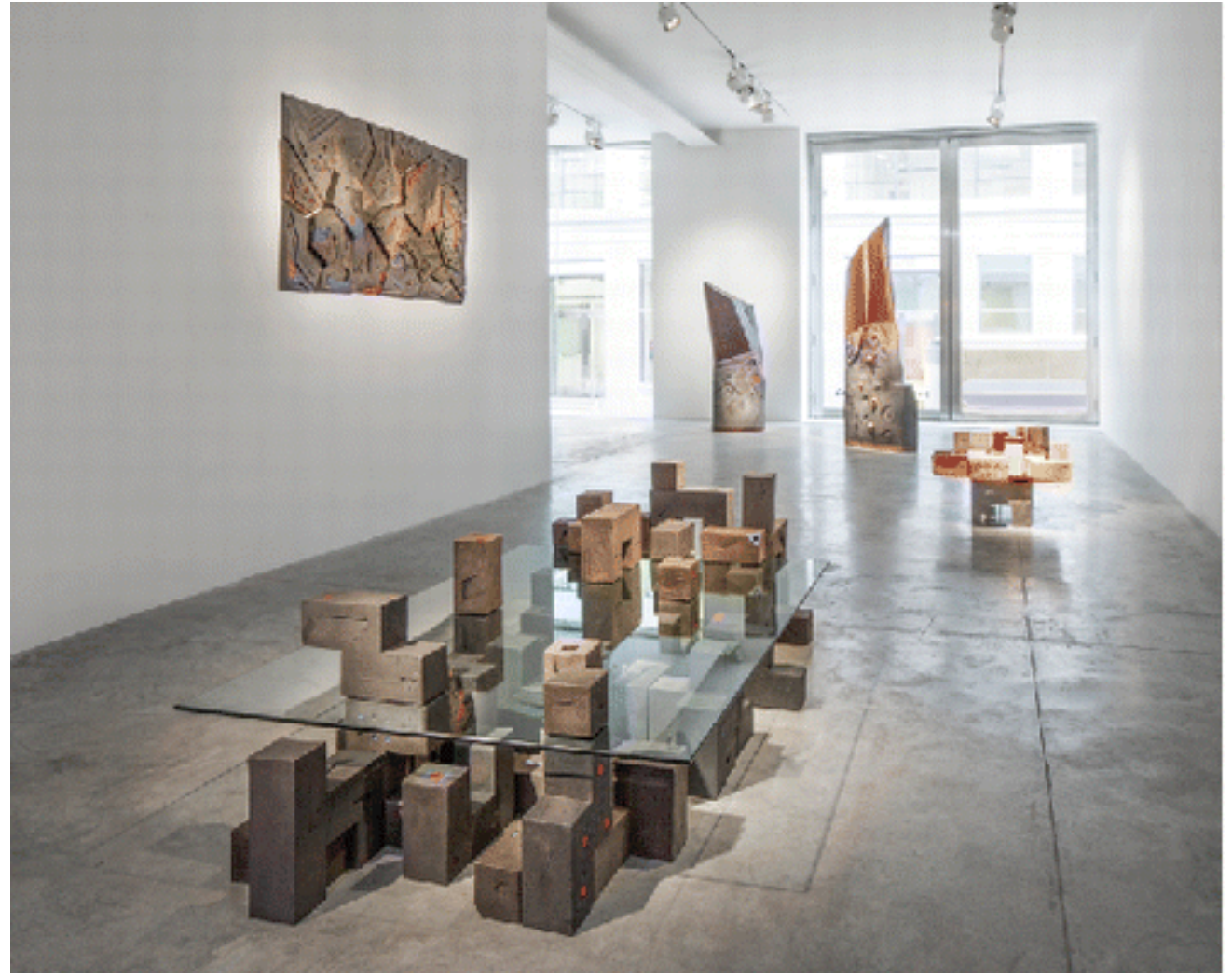

Figure 4. Camagu, installation image, Friedman Benda Gallery, New York, NY, June 23August 19, 2016. Photo credit: Daniel Kukla. 
Dyalvane is clearly conscious of and seeks to confront both this intra-continental issue and, simultaneously, is face to face with the physical and economic gentrification of Cape Town itself. This port city has become one of the most desirable destinations in the world and struggles with the gentrification one would expect of this title. Over the past five years Dylavane's ceramics have been direct reflections on the changing face of Cape Town. His work at first reflected the industrial port structures of cranes and shipping containers, including his extremely well-received coffee-table series mimicking the forms of international shipping container forms in a Tetris-like jigsaw puzzle (Figure 4). His industrial cityscapes then transitioned to reflect construction cranes viewed from his studio window in the up-and-coming neighborhood of Woodstock. As galleries sprang up like weeds, bed-and-breakfasts, coffee shops, and interior design boutiques rapidly engulfed the neighborhood. Dyalvane eventually shifted to a smaller studio with a less opulent view and a more reasonable rent. Yet he is also an insider who has also thrived in and been nurtured by the artistic ports of South Africa.

After receiving his first degree at the Sivuyile Technical College in 1999, Dyalvane studied at the Nelson Mandela Metropolitan University (NMMU, and Nelson Mandela University as of 2017) in Port Elizabeth. This industrial port city has long been known as a center for ceramics in South Africa. NMMU was founded through the merging of two universities and a technikon (a structure akin to a technical college), and some of the top names in South African ceramicsHilton Nell, David Moss, Meshack Masuku, and Charmaine Haines_-graduated from or worked at Port Elizabeth Technikon. Additionally, Port Elizabeth's educational facilities consistently maintained close ties to the Nelson Mandela Metropolitan Art Museum, which actively collected ceramics following its founding in 1956 and still holds the Ceramics Southern Africa (Eastern Cape) Annual Regional Exhibition on an annual basis. Ceramics Southern Africa (CSA), founded in 1974, is a key part of the ceramics and design-oriented infrastructure that has provided a route for Dyalvane's work to reach an international audience.

Earning his National Diploma in Ceramic Design in 2003. Dyalane received a scholarship to attend NMMU from the Potter's Workshop, a utilitarian-ware production ceramics studio based in Muizenburg, Cape Town. The NMMU program is known as one of the most technically rigorous programs in the nation, actively encouraging students to understand hand-built and industrial forming techniques, firing and glaze chemistry, and the entrepreneurial aspects of ceramic production. As in many other Anglophone countries deeply impacted by the legacy of famous British ceramist Bernard Leach and his many followers, South Africa developed publications, awards, exhibitions, and workshops for this medium beginning in the 1950s. Practitioners of Arts and Crafts Movement-based ceramics and later factions of modernist, postmodern, and contemporary ceramists have maintained regional and national infrastructures. Under apartheid, the ceramic art world intermittently celebrated Black South Africa ceramists in limited capacities. Journals and awards acknowledged indigenous low-fired ceramics as part of the overall South African ceramics world throughout the 1980s and 1990s. Nevertheless, this largely White art world has struggled to diversify its membership in the post-1994 era.

During the late 1990s and early 2000s Dyalvane was celebrated as a shining example of the "New South Africa," in a ceramic art world struggling to shed its guise of privileged White artistic practice. This is a medium that is economically prohibitive. Rural women continuing traditions of bonfired ceramics find transportation and raw materials are often poorly 
compensated by standard prices for ceramic wares. In urban spaces, capital investment in imported kilns and glaze chemicals, as well as the often exorbitant cost of electricity, can spell the end of many a small entrepreneurial venture. Dyalvane was all the more admired because he defied the odds and was able to sustain a small business despite high capital outlays and low profit margins. Of course, Dyalvane's aesthetic innovations were equally impressive. Using white stoneware clay, a high-fired clay that matures at approximately $2150^{\circ} \mathrm{F}$ and $2260^{\circ} \mathrm{F}$ $\left(1160^{\circ} \mathrm{C}\right.$ and $\left.1225^{\circ} \mathrm{C}\right)$, Dyalvane developed a striking ceramic cutting technique (Figure 5) that began winning him awards as early as 1999 with the FNB (First National Bank) Vita Award for Best Exhibition Piece from the Western Cape. He would go on to win the FNB Vita at the national level as well as many other accolades.

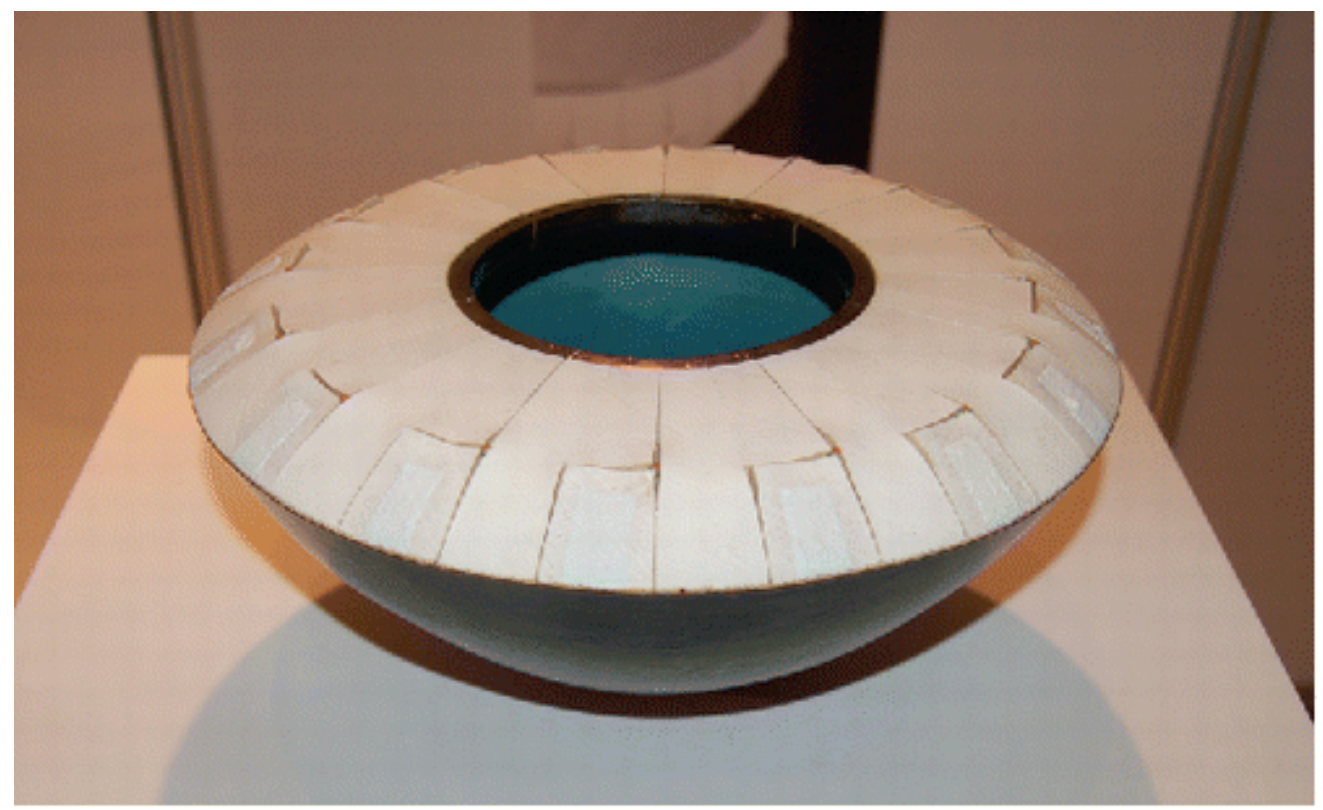

Figure 5. Andile Dyalvane, Vessel. Winner - Ceramics Category, Cape Town Design Indaba, 2006. Photo credit: Elizabeth Perrill.

To create this particular effect, Dyalvane cuts partway through the surface of his vessels. With pressure from the interior of the vessel, the cut is then forced open. At times a pellet of clay is carefully inserted into the cut, making reference to the method of scarification and application of healing substances within Xhosa cultural practices. With these methods Dyalvane honors his active connections to his rural home of Ngobozana, in the Eastern Cape province of South Africa. Dyalvane works extensively with glaze experimentation to achieve spectacular color combinations and extremely precise highlights on his forms. He has also continued to develop and transform his techniques to highlight architectural motifs in his work. His research and innovation on both the technical and iconographic aspects of his work have caught the attention of a broad range of art worlds in South Africa and beyond.

The timing was impeccable for Dyalvane's inclusion in the 10 Years of Democracy exhibition at the Cape Craft Design Institute (2003); the Picasso and Africa exhibition (2006), for which he created a series of works that combined his signature cut-surface ceramics and Picasso-inspired faces (Figure 6); and the Design South Africa exhibition in Atlanta, GA (2008). During this period, Dyalvane's consistent participation in international events, such as the South African 
Design Indaba, a trade show that brings buyers from the entire world to Cape Town, exposed him to the numerous design contracts that have been offered to and often have been accepted by South African designers in ceramics, furniture, jewelry, and homeware. It has been commonplace for design work from South Africa to be commissioned by substantive international corporations, including West Elm, Anthropologie, and, most recently, Ikea, which will launch its Africa design line in 2019. Dyalvane seems to be aware of the benefits and dangers of international design work. During this past decade, he has conscientiously fostered ties to his rural roots and to Xhosa spirituality in both is life and work. Returning to Ngobozana, Eastern Cape, and simultaneously pushing himself toward a solo career embedded within a community of local artists, Dyalvane has laid the groundwork for what would become the Camagu philosophy, a mantra that he has most recently manifested in his work, exhibitions, and social media presence.

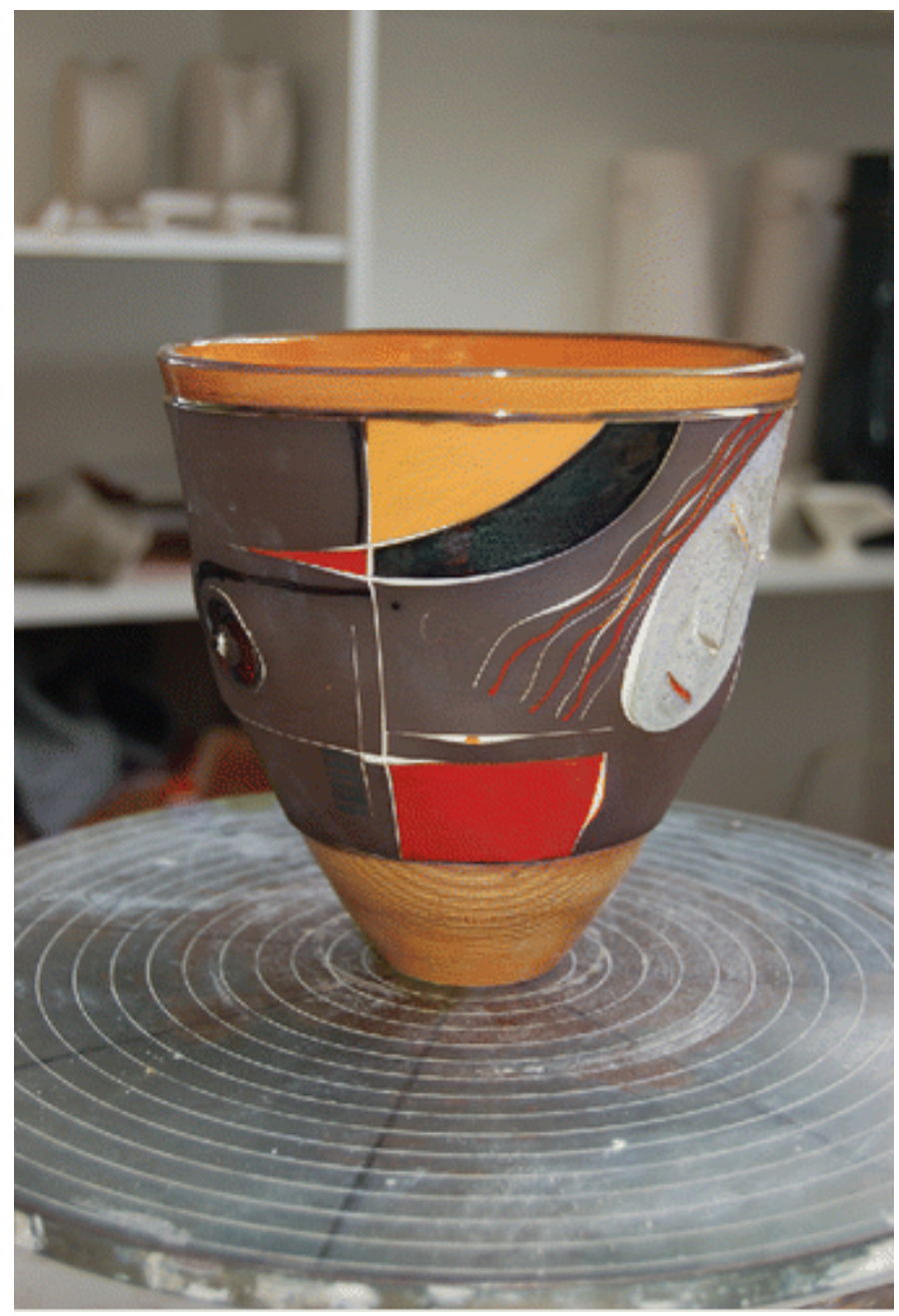

Figure 6. Andile Dyalvane, Vessel based on Picasso and Africa exhibition, 2006. Photo credit: Elizabeth Perrill.

Camagu translates from Xhosa as "we are grateful," and it is a term that has also been used by Xhosa-speaking fashion designer Laduma Xgxokolo, who named his 2015-2016 capsule collection Camagu. Dyalvane's Camagu philosophy is expressed through his integration of a solo 
career with the constant mutual support of his shared business, Imiso Ceramics. In 2006 Zizipho Poswa and Dyalvane, who both attended NMMU, began this successful and largely utilitarian ceramic company. Poswa, while also a ceramist, holds a degree in textiles and surface design from Cape Peninsula University of Technology. She and Dyalvane have ensured that Imiso's ceramic production has been disseminated through design platforms and that they were never cloistered into the ceramics niche market (Figure 7). In the pivotal year of 2006, Dyalvane also won the Western Cape Design Icon award from the Cape Craft and Design Institute and an Elle Deco International Design Award from Elle Décor. The business partnership with Poswa and the Imiso production team, which employs several professional ceramicists, is clearly a grounding force.

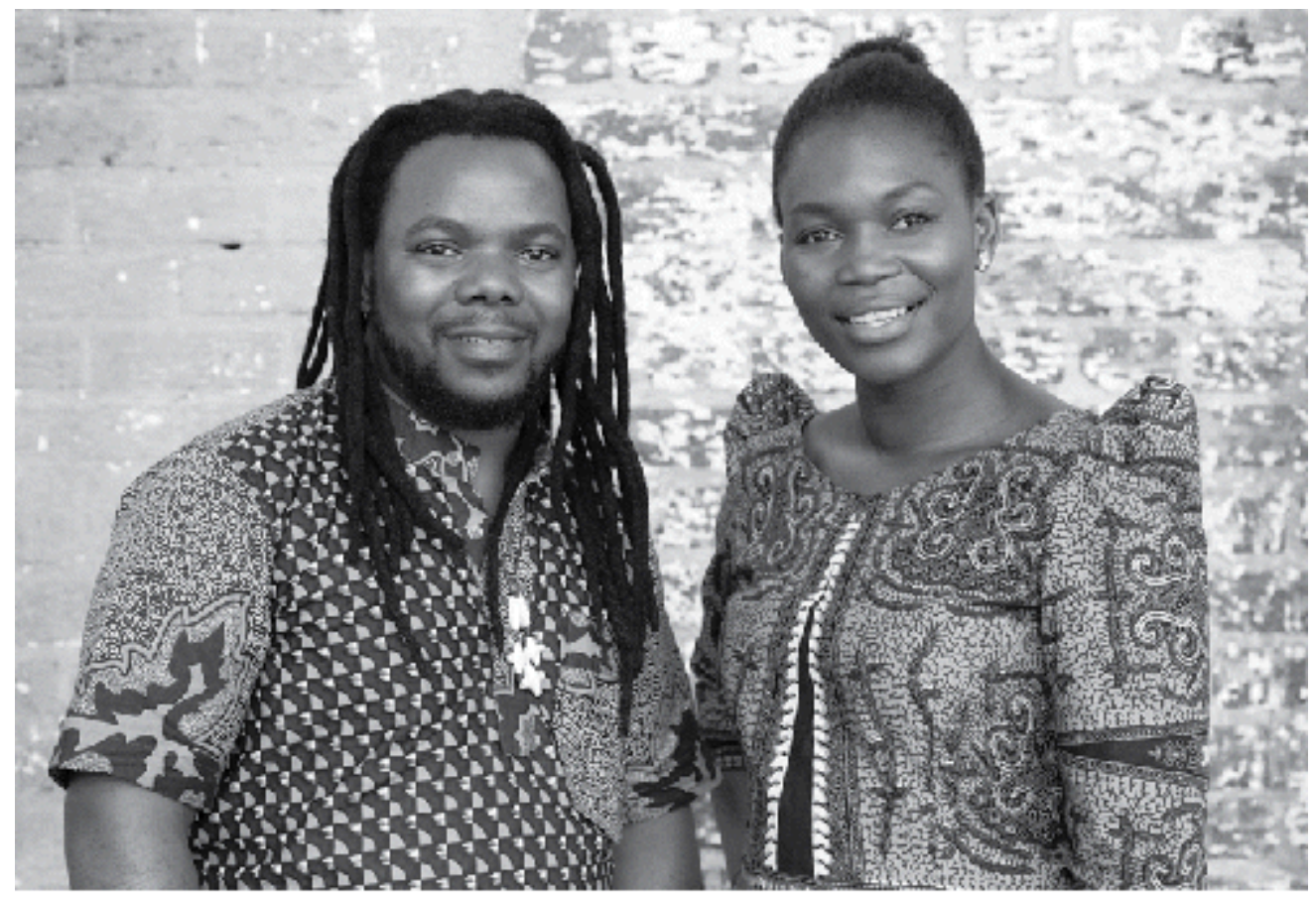

Figure 7. Andile Dyalvane and Zizipho Poswa, founders of Imiso Ceramics. Photo credit: Imiso Ceramics.

The ability to juggle press contacts, award and exhibition applications, PR engagements, and social media presence required of intersecting, but not consistently overlapping, social sets is perhaps as impressive as Dyalvane, Poswa, and the Imiso team's formal and technical mastery in the ceramic medium. Another critical relationship for Dyalvane has been his collaboration with Southern Guild, a gallery opened in 2008 that has taken his work to Design Miami, Design Miami in Basel, Design Days Dubai, and several other international venues. Trevyn and Julian McGowan, Southern Guild gallery founders, have been advancing several design-oriented careers across artistic media. Additionally, Dyalvane has engaged in international residencies that have solidified his ties with various art worlds. As artist in residence at the New Taipei City Yingge Ceramics Museum in 2014 (Figure 8), Dyalvane was able to connect with key ceramic curators and artists from Australia, China, Italy, Japan, Korea, the UK, the United States, and throughout Europe. The international profile Dyalvane has developed and his clearly grounded practice have led to his most recent accolade as a member of the AIC (Académie Internationale 
de la Céramique), an NGO based in Geneva, Switzerland that is an official partner of UNESCO (AIC).

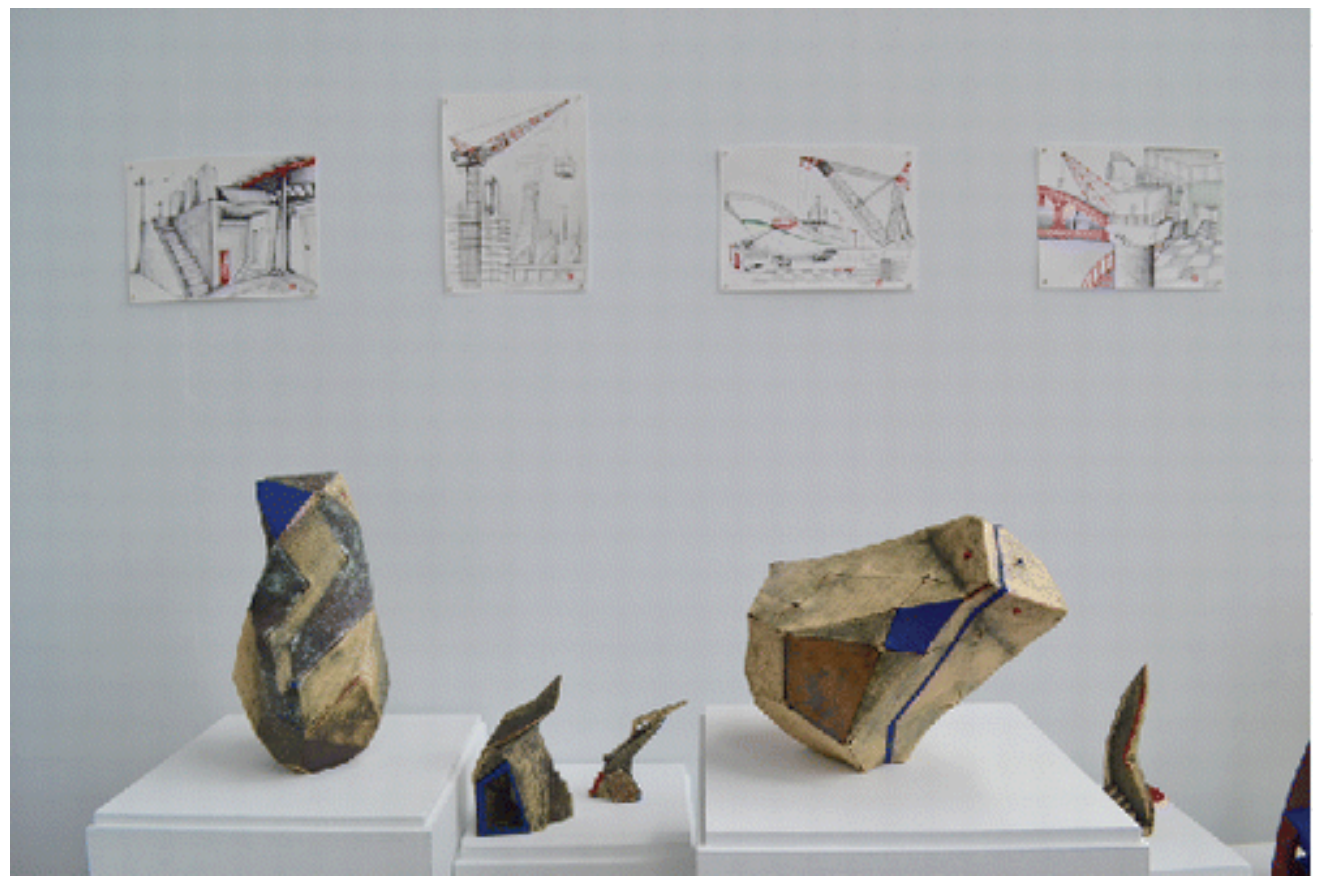

Figure 8. Drawings and ceramics by Andile Dyalvane. Installation image, Terra Nova: Taiwan Ceramics Biennale, Yingge Ceramics Museum. New Taipei City, Taiwan, 2014. Photo credit: Elizabeth Perrill.

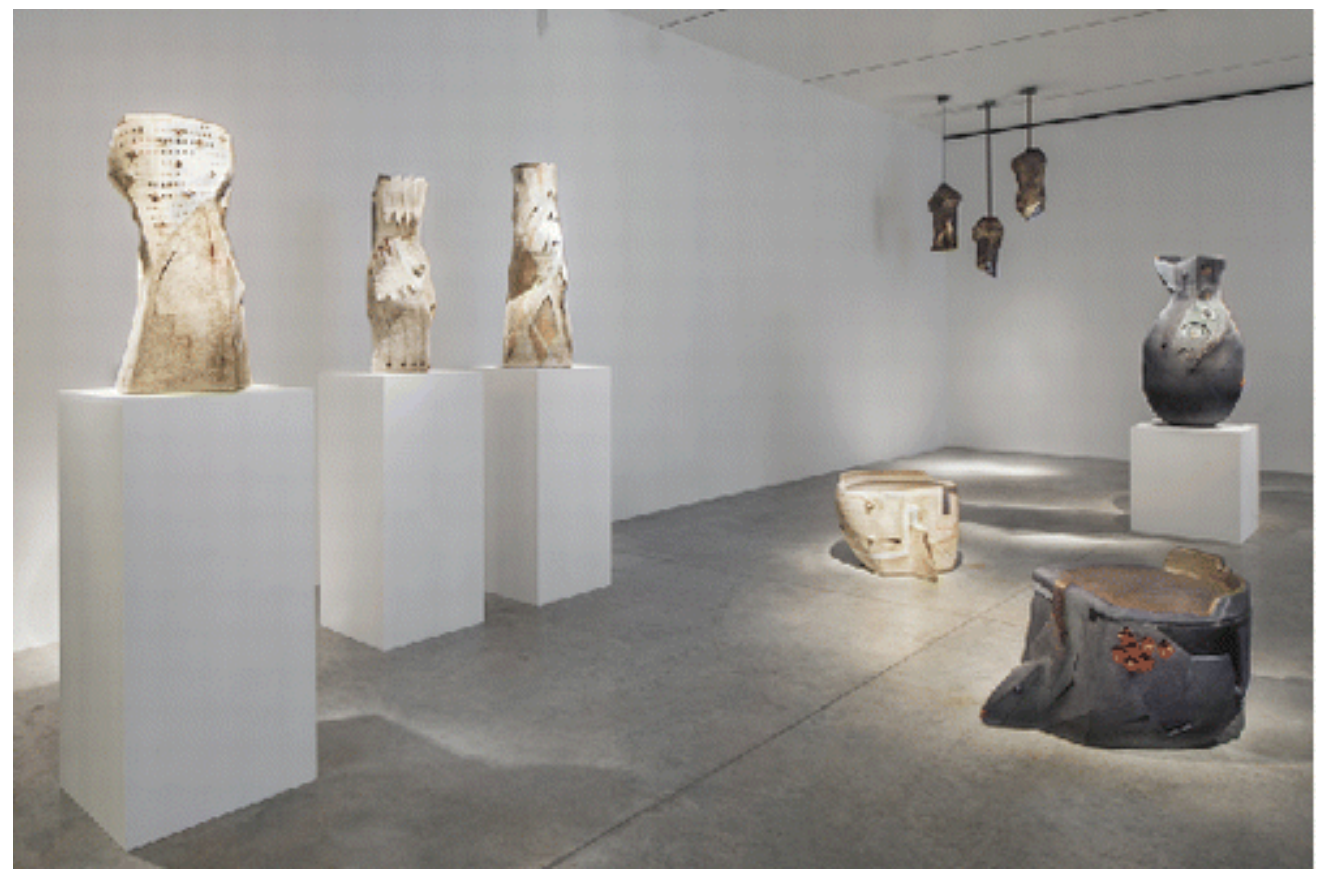

Figure 9. Camagu, installation image, Friedman Benda Gallery, New York, NY, June 23August 19, 2016. Photo credit: Daniel Kukla. 
The June 2016 opening of the Camagu solo exhibition at the Friedman Benda gallery in New York (Figures 9 and 10) and the September 2017 opening of Idladla (Figures 11 and 12) in Cape Town's newly opened Silo District are the most recent achievements in what has been a decade of ever-growing international and national success. The Idladla exhibition runs parallel to the opening of the Zeitz MOCCA museum, and Dyalvane's work is also included in Stellar, a multimedia group show that ran parallel to Zeitz MOCCA's opening events in the Silo District. Dyalvane's solo exhibition riffs on the trendy location of the silos turned exhibition spaces. He has created forms that reference grain storage bins he encountered while traveling near Albany, NY; Malian grain storage bins made of ceramic and earth materials; and the concepts of gratitude, preservation, and at times loss conveyed by Camagu that tie him to his rural Xhosa upbringing. Dyalvane's silos simultaneously provide a tongue-in-cheek joke about the venue in the silo district while still bringing viewers back to the symbolic weight of preservation, bounty, and community that are the true roots of grain storage.

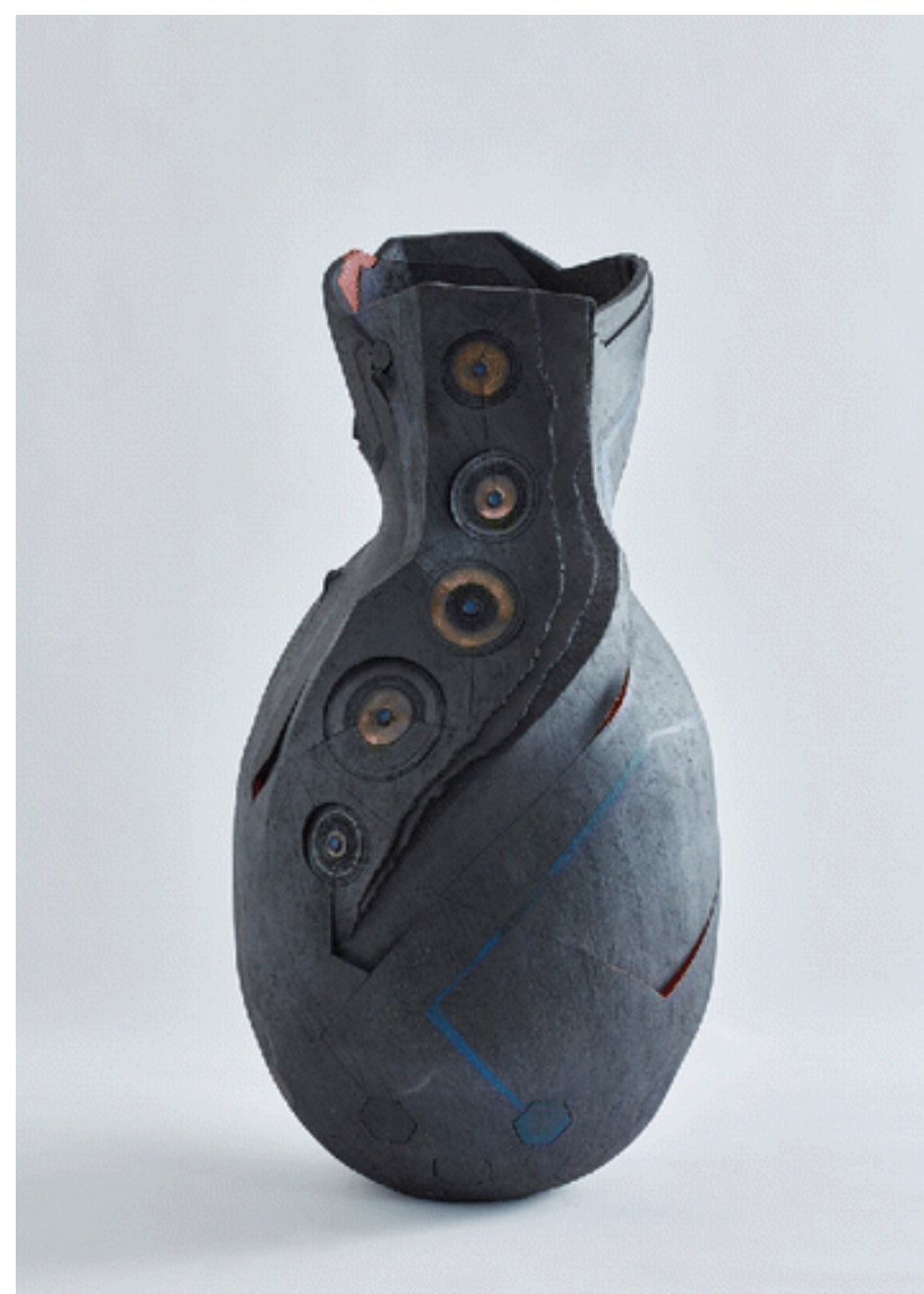

Figure 10. Andile Dyalvane, Camagu (Gratitude), 2016, Black Clay, $39.25 \times 19.75 \times 19.75$ in. $(100 \times 50 \times 50 \mathrm{~cm})$. Photo credit: Southern Guild. 


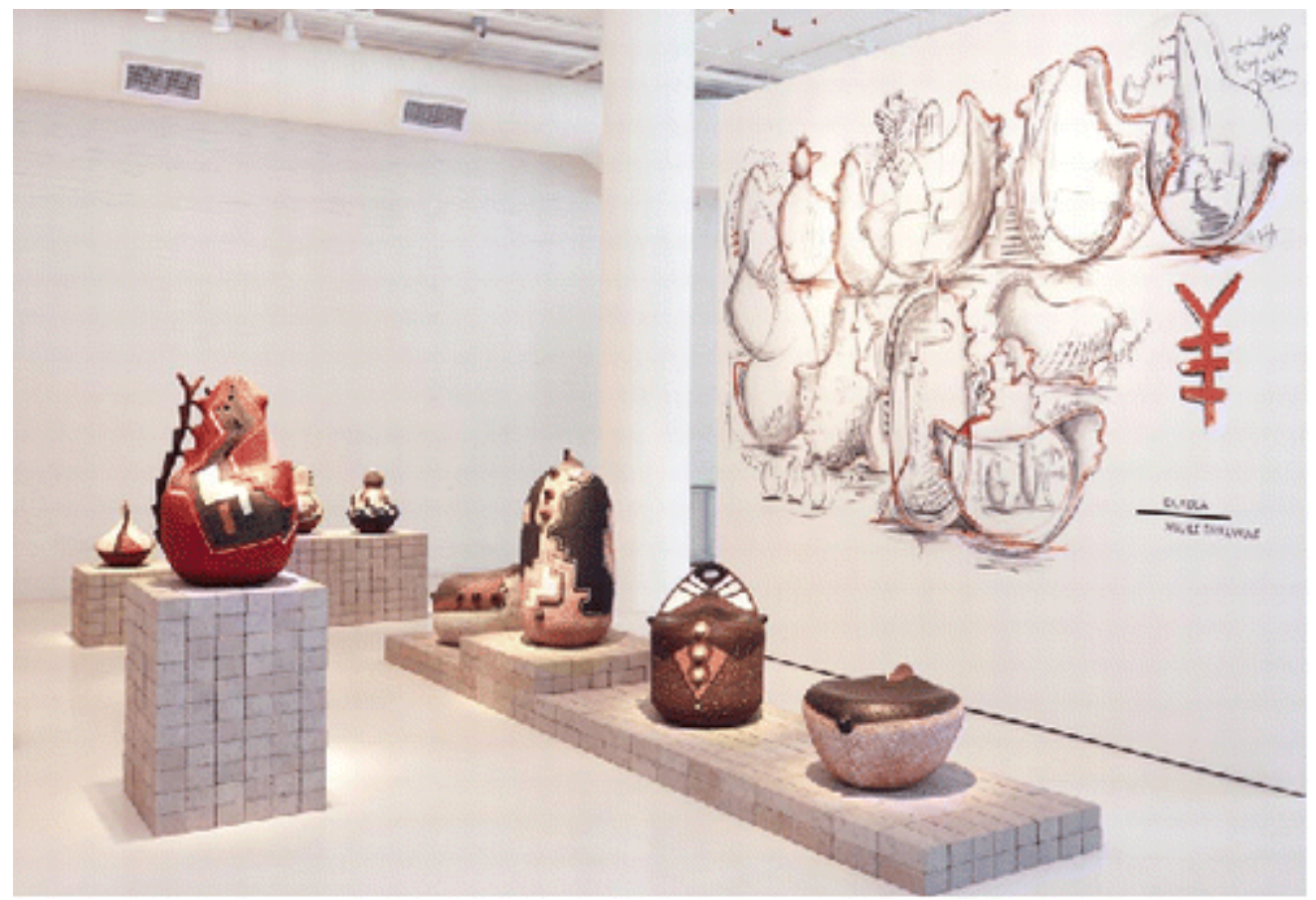

Figure 11. Andile Dyalvane, Idladla, Installation image, Southern Guild, Cape Town, South Africa, Sept. 14-Oct. 9, 2017. Photo credit: Micky Hoyle.

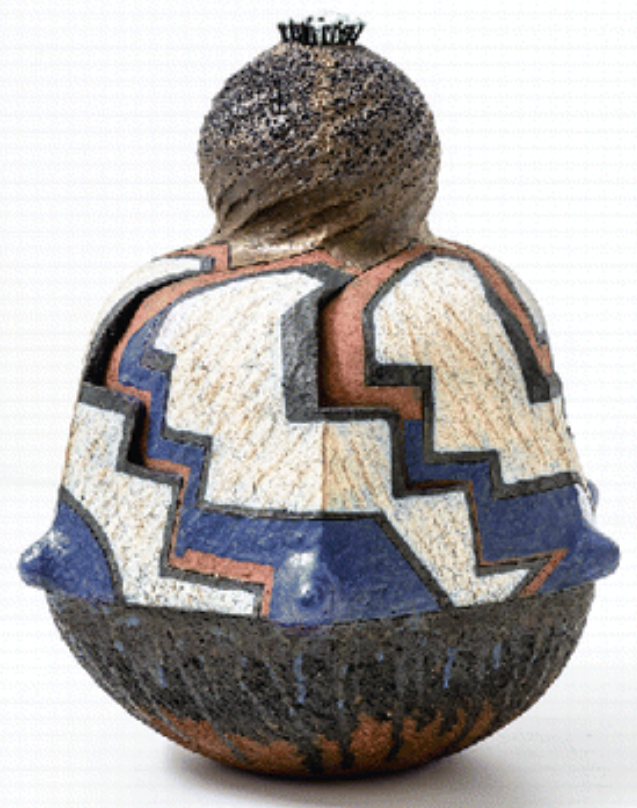

Figure 12. Andile Dyalvane, Isigezenga (Corn Bread), 2017. Photo credit: Adriaan Louw. 
Dyalvane's works bring us back to the struggle with artistic gentrification that thoughtful South Africa artists are necessarily confronted by. The silos that the new Zeitz MOCCA museum are constructed from were originally built to ensure the extraction of wealth from South Africa. They are icons of conspicuous consumption and wealth run rampant, both in the past and the present. Thus the depiction of more humble silos that original guarded seeds for the coming year in upstate New York, Mali, or rural South Africa give one pause. As views of harbor shipping rigs have turned to grain silos and abstracted seating forms, places for reflection that comment on the need for preservation, Dyalvane has fully expressed his Camangu philosophy, the idea that one must be grateful and preserve history to succeed within the present day (Figure 13). Two of these forms iMpukwe'dladla (Grain Silo Rat) and iNgqokoqhwane (Kernel Weevil) bear the names of threats to grain. Metaphorically, these works refer to the various threats to the preservation of local knowledge and value structures. Dyalvane's work has reflected the growing philosophical core of his work. The physical gentrification and rapid transformation of Cape Town over the past decade has sparked a sense of introspection in Dyalvane. As he both looks outward toward connections to the silos of upstate New York or Mali, he has also dug into his own history and linguistic roots - tendencies that are increasingly reflected in his ceramic production.
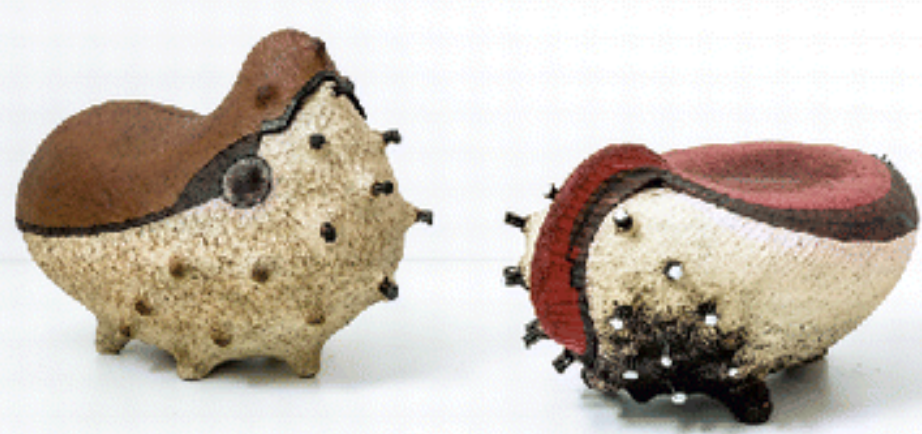

Figure 13. Andile Dyalvane, iMpukwe'dladla (Grain Silo Rat) and iNgqokoqhwane (Kernel Weevil), 2017. Photo credit: Adriaan Louw.

The multiplicity of art worlds that are impacting today's urban Cape Town is beyond the bounds of siloed academic enclaves of African art history, contemporary art history, or the history of ceramics. Indeed, the structure through which Dyalvane has entered into global art markets, design markets, and ceramic markets complicate and call into question the continued use of the term "the African art market." This singularity disintegrates in the fluidity of Dyalvane's artistic and economic realities. The challenge and the delight for scholars seeking to track the expansion of these fluid systems of art sales is that we must also expand our reading and thinking tools. The 
work of Christopher Steiner, Ruth Phillips, Sydney Kasfir, James Clifford, and others forms a canon of market-oriented scholarship that grounds the field and is reflected in this special issue. Simultaneously, we must follow the artists' lead, through which we are pushed to engage with new theories and intellectual synergies. The work of Partha Mitter, Oriana Baddeley, and Toshio Watanabe on transnational artistic practice, ${ }^{2}$ Kobena Mercer on the aesthetics of hybridity, Gilane Tawadros on the status of intellectual property, or Rita Felski on the reframing of the ties between art and society as well as local systems of philosophy and value that are meaningful to artists practicing within specific places come to mind as sites of scholarly inspiration. Just as Dyalvane and his ilk have both expanded far beyond the bounds of standard routes of global marketing and consumption, while simultaneously digging into local meaning, so must we as scholars expand our bounds while retaining our foundational texts.

\section{Notes on contributors}

Elizabeth Perrill (eaperril@uncg.edu) is an Associate Professor at the University of North Carolina at Greensboro, as well as Consulting Curator for African Art at the North Carolina Museum of Art, Raleigh. Her primary research interests include histories of Southern African ceramics, South African contemporary art, and economic histories of ceramic arts in the modern and contemporary eras. Perrill's single-author works include Zulu Pottery (2012) and Ukucwebezela: To Shine (2008), as well as many articles on Zulu ceramics and South African contemporary art. Thanks to Kagiso Makgalamele at the Guild Group, the entire Imiso team, and all attributed photographers for assistance with figures for this article.

\section{References}

AIC. Académie Internationale de la Céramique, New Members 2017, Andile Dyalvane. Retrieved from http://www.aic-iac.org/en/member/andile-dyalvane/ [Google Scholar]

Felski, R. (2015). The limits of critique. Chicago, IL: University of Chicago Press. [Google $\underline{\text { Scholar] }}$

Mercer, K. (2016). Travel and see: Black diaspora art practices since the 1980s. Durham, NC: Duke University Press. [Google Scholar]

Okeke-Agulu, C. (2017). Modern African art is being gentrified. Sunday review, opinion. the New York Times. Retrieved from https://www.nytimes.com/2017/05/20/opinion/sunday/modern-african-artsothebys.html [Google Scholar]

Onuzulike, O. 2013 Emergence of Modern Ceramics in Nigeria: Kenneth Murray's Experiments, 1929-1939. The Journal of Modern Craft, 6(3), 293-314. [Google Scholar]

Rodgers, B. (2015, September 16). El Anatsui Found Resonances of Both Fragility and Resilience in Clay. [online article] Retrieved from, https://cfileonline.org/art-anatsui-

\footnotetext{
${ }^{2}$ Partha Mitter, Oriana Baddeley, and Toshio Watanabe, "Nation, Identity and Modernity, Visual Culture of India, Japan and Mexico, 1860s-1940, Research Project," University of the Arts London Research Centre for Transnational Art, Identity, and Nation (TrAIN). London, 2001-2004. This model collaborative project yielded multiple publications and exhibitions.
} 
found-resonances-of-both-fragility-and-resilience-in-contemporary-ceramic-art/ [Google Scholar]

Smith, T. (2011). Review, El Anatsui: When I last wrote to you about Africa. Royal Ontario Museum, Toronto, Oct. 2, 2010-Jan. 2, 2011. NKA: Journal of Contemporary African Art, 28, 142-145. [Google Scholar]

Tawadros, G., ed. (2004). Changing states: Contemporary art and ideas in an era of globalisation. London, UK: Institute of International Visual Arts. [Google Scholar] 